\title{
Genocide in Myanmar
}

The Rohingya and Burmese-Buddhist Ethnonationalism

\author{
AUTHOR: Matthew Sparling \\ EDITED BY: Joshua De Pinto, Julian Matheson, and Marisa Coulton
}

The history of Burma, now Myanmar, is an intricate tale woven between an exclusionary identity founded on Burmese-Buddhist nationalism, and the politics of imperialism and decolonization. The result has been successive inter-state conflicts throughout the late-twentieth century, culminating in an ongoing violent episode beginning in 2012 perpetrated primarily against Rohingya Muslims living in the south-west state of Rakhine. This essay intends to examine this conflict, contextualize it within Burmese history, and ultimately determine whether it should be classified as an insurgency, as ethnic cleansing, or as a genocide. To do this, a brief history of the current conflict will be discussed, including historical context explaining its roots. Next, the concept of "insurgency" will be defined and discussed in light of the founding of the Arakan Rohingya Salvation Army (ARSA), a new insurgent group in Rakhine. "Ethnic cleansing" will then be discussed and compared to the case of the Rohingya in light of sociologist Michael Mann's definition of the term. Lastly, genocide will be defined using the United Nations' Convention on the Prevention and Punishment of the Crime of Genocide (herein referred to as "the Convention") and set against the Rohingya in Myanmar to assess its validity as a label for the crisis. Ultimately, this essay will argue that "insurgency" and "ethnic cleansing" are inadequate labels in understanding the violence perpetrated against the Rohingya, and that the conflict beginning in 2012 should be classified as a genocide according to the Convention.

Theoretical concepts must first be established to properly analyze the plight of the Rohingya. In The Dark Side of Democracy, Michael
Mann writes about "murderous ethnic cleansing" as a broad term which encompasses concepts like genocide, essentially referring to the purposeful erasure of an ethnic group through violent means. ${ }^{1}$ Mann notes that murderous ethnic cleansing is more likely to occur in newly democratic regimes than stable authoritarian regimes, as the demos and ethnos of multiethnic states become "entwined." Furthermore, democracies will become less democratic as ethnic cleansing escalates. Central to this, however, is ethnic group competition over a piece of territory. In this case, it would be Rohingya and Buddhist groups - joined by the government and military - claiming Rakhine State. The last step before "murderous ethnic cleansing," he argues, is for a dominant group to have confidence in its "overwhelming military power and ideological legitimacy."3 Buddhist groups have largely reached this stage in Rakhine, and are further emboldened to carry out murderous ethnic cleansing as a result of identity reproduction by creating an "other" in the Rohingya. ${ }^{4}$ In Myanmar's Enemy Within: Buddhist Violence and the Making of a Muslim 'other,' Francis Wade delineates this through "difference," whereby those who belong and those who do not are distinguished, and the latter are made to be "threatening." Anthropologist Mikael Gravers takes this further and uses Stanley Tambiah's work on ethnic conflict, which understands violence as playing a key part of identity formation in ethnonationalist conflicts. Violence "attains its own autonomy, becomes efficacious in the reproduction of ethnic identity and solidarity, and finally violence becomes synonymous with a righteous cause," and helps separate the in-group from the "other."6 These concepts are critical to understanding the 
relationship between Buddhists, Burmese and the Rohingya, and why violence is being perpetrated.

Pervasive throughout Myanmar is the concept of "taingyintha," or "sons of the soil." This differentiates ethnicities which are viewed to be "native" to Myanmar, and therefore superior to other ethnic identities. It also decides "belonging" in Myanmar, as the country sees citizenship as dependent solely on ethnic or national identity. The Rohingya are not among the ethnicities of Myanmar who have been labelled taingyintha, although Buddhists are. ${ }^{7}$ The dominant Buddhist sect in Myanmar is Theravada Buddhism. Theravada Buddhism connects religion with the state, and sees the state as the primary guarantor of the safety of Buddhism. ${ }^{8}$ While it should not necessarily be associated with "extreme nationalism and intolerance," it is vulnerable to ideologies which profess the creation of a 'pure' polity. This has happened in Myanmar, as Political Theorist Matthew Walton notes, and Buddhism and nationalism have become intertwined. Part of this is due to the othering process previously discussed, as many "extremists" believe that the goal of Muslims is to ultimately replace Buddhism in Myanmar with Islam. ${ }^{9}$ Part of the process to combat this has been the deconstruction of Rohingya identity by the Myanmar government. For example, they refuse to refer to the Rohingya by this name, instead preferring "Bengali," suggesting that the term "Rohingya" is a very recent construction. ${ }^{10}$ A multiethnic state is being transformed into a monoethnic state dominated by a combined Burmese-Buddhist identity which excludes nonconforming ethnic groups like the Rohingya. ${ }^{11}$

The exclusionary identity currently endemic to Myanmar has roots in the 11th century, through a combined identity which was dually Bagan (Burmese) and Buddhist under King Anawrahta's expansionist kingdom. ${ }^{12}$ Muslims have occupied this region since at least the eleventh century as well, and former Burmese rulers invaded the Rakhine area only in the eighteenth century. However, the British annexed Rakhine in the early nineteenth century during the First Anglo-Burmese War, and all of present-day Myanmar by the end of the nineteenth century as an extension of British India. Due to this, many Indian Muslims were able to travel to Burma as part of the British "elite." This juxtaposition of Indian Muslims beside British colonists began the process of animosity between Buddhists and Muslims. ${ }^{13}$

The geography of British rule in Burma was altered in 1937. Burma became a separate administrative zone from India, and the borders were redrawn to reflect the Burmese kingdom prior to the First Anglo-Burmese War. This had the consequence of including the Rakhine region into Burma which was ethnically distinct from traditional Burma. Ibrahim takes note of this, writing that "the new administrative unit thus integrated Arakan (Rakhine) into what was to become, a mere ten years later, the newly independent country of Burma. This purely administrative decision is what led to the situation we are in today." ${ }^{4}$

During the Second World War, the Rohingya and Buddhists living in Rakhine fought one another; the former for the British and the latter for the Japanese. As a result, the Rohingya were largely pushed to the North of the Rakhine region toward now-Bangladesh, and the Rakhine Buddhists were largely pushed South. This is an extension of the Muslim-Buddhist divide driven along colonial lines in Burma. Similar to the nineteenth century, Rohingya were given administrative posts in Rakhine as a result of their work with the British Empire and were seen as "new colonisers" and "lackeys" of the British. ${ }^{15}$ This not only "sowing the seeds of deep resentment among Rakhine Buddhists," but also established the notion that Rohingya are militants working against the Burmese-Buddhist way of life. ${ }^{16}$

Independence was officially granted in 1948, and the 'Burmanisation' of the country began in the 1950s. All government business and education would be conducted in Burmese, and history was taught from the perspective of Burman nationalism. These were the first attempts by the 
Burman state to assimilate its citizens into Burman culture. ${ }^{17}$ The Tatmadaw (military) launched a successful coup in 1962. The military government presented the internal problems in Myanmar in existential terms, further manipulating the "lines of difference," especially in Rakhine. ${ }^{18}$ On the civilian side, the majority of Burmese saw the British failure to create a Buddhist-Burmese as something which could be corrected now, founded on Theravada Buddhist principles of the state and Burmese language and culture. ${ }^{19}$ The pervading belief was that "[Burma] could only survive as a nation if foreign influences were purged," exemplified in the maxim, "One voice, one blood, one nation."20 The first major rounds of violence occurred in 1972 and 1991 , and both were very similar. In both cases, the military went into the "border regions" of Myanmar to "scrutinize" inhabitants. The military perpetrated mass violence against the Rohingya, each time displacing over two hundred thousand Rohingya to Bangladesh, and in 1972, killing ten thousand. ${ }^{21}$ Violence against the Rohingya, therefore, should be understood as a continuity which has always aimed to eradicate them from Myanmar.

The Citizenship Act of 1982 began the dismantling of Rohingya legal identity. The military government sanctioned 135 official "indigenous ethnic groups," who could claim legal status as Burmese, while "outsiders to these groups were denied citizenship and legal status" and prevented from obtaining identity cards. ${ }^{22}$ The narrative spread by the government, already accepted by Burmese nationalists, painted the Rohingya as "Bengali interlopers" who had been illegally immigrating to Burma for decades. This was characterized as an attempt to "claim citizenship and begin the Islamisation of Myanmar."23 In 2008 the State Law and Development Council, the military junta at the time, enshrined a new constitution which retained them as the sole "guarantor of Myanmar" and entrenched the Rohingya as non-citizens, rendering them stateless people. ${ }^{24}$

The conflict in Rakhine state, which is most familiar to those outside of Myanmar, began in
2012. According to census information analyzed by the United Nations Human Rights Commission, approximately 1.09 million Rohingya lived in Rakhine prior to the mass exodus beginning in 2012. Journalist Tun Khin puts this number at around 1.3 million. ${ }^{25}$ This puts the Rohingya at approximately 25 per cent of the total population of Rakhine, while approximately 90 per cent of Myanmar is Buddhist. ${ }^{26}$ The 2012 violence was catalyzed by a series of events beginning with the rape of a Buddhist girl by three Muslim men. A few weeks later, three hundred Rakhine Buddhists retaliated by attacking a bus of Muslims unaffiliated with these men, killing ten. Rohingyas responded by burning down a Rakhine village, seen as a precursor to "impending conquest" by Rakhine Buddhists. ${ }^{27}$ Believing in their mission to purify Myanmar, Buddhists began where the military left off and preached the need for ethno-religious purity, which would be achieved through violence. This "purification" process would be repeated in the years following the 2012 conflict. $^{28}$

The violence of 2012 had lasting effects. Firstly, 120,000 Rohingya became internally displaced persons (IDP) forced into refugee camps within Rakhine state. ${ }^{29}$ An additional twenty thousand ended up in Thailand between October 2012 and April $2013 .{ }^{30}$ Secondly, while the violence was initiated and mostly perpetrated by Rakhine Buddhists against the Rohingya, security forces and police eventually joined in the attacks. They helped burn Rohingya villages, and opened fire on Rohingya civilians. Furthermore, President Thein Sein would describe the Rohingya as non-citizens and express his desire to deport them to other countries, later declaring that the Myanmar military would "eradicate them until the end!" and that he believed the military was already doing it. ${ }^{31}$ This entered public discourse as part of the narrative regarding the Rohingyas. The deep anxiety toward non-Buddhists and the desire to purge them from the state is deeply important to the history of Burma/ Myanmar since 1948.

A refugee crisis emerged in 2015, which 
Ibrahim notes was not out of any particular event, but simply due to the "intolerable conditions" Rohingyas were living in. ${ }^{32}$ Violence in Rakhine would worsen after the 2015 democratic elections, which were largely hailed internationally as a success for Myanmar. As Michael Mann argues, the transition to democracy plays a part in escalating ethnic violence on the path to "murderous ethnic cleansing." ${ }^{33}$ This was true in Rakhine, as Buddhists believed that providing power through democratic rights to Rohingya would allow them to Islamise Myanmar. ${ }^{34}$ To prevent this, Rohingya were barred from voting or running in the 2015 election based on their inability to produce a "citizenship card," which is a legacy of the 1982 Citizenship Act. ${ }^{35}$ As a result, Rohingya have no representatives within the legislature, something which did not happen under military rule, representing a lessening of democratic values in Myanmar. ${ }^{36}$

In October 2016, the frustrations of Rohingya living in Rakhine came to a head when ARSA attacked three separate Border Guard Police (BGP) outposts and stole guns and ammunition. ${ }^{37}$ The response by the Tatmadaw was staggering. Information Minister Pe Minyt likened the attack to a Myanmar version of $9 / 11$, eighty thousand Rohingya were displaced by military action, and twenty thousand immediately fled to Bangladesh. ${ }^{38}$ The military contemplated arming Rakhine Buddhist militias to "defend" against the Rohingyas, and did recruit one hundred-twenty non-Muslims into a supposed militia wing of the Border Guard Police. ${ }^{39}$

The most recent escalation occurred in August 2017 after ARSA again attacked twenty police stations, government offices, and a military base, killing several government officials. ${ }^{40}$ The reprisals by the military were taken out against the civilian Rohingya population similar to the violence in 2016. Homes and communities were burned to the ground, Rohingya were tortured, extrajudicial killings of men, women, and children was considered the norm, systematic rape was widespread, Rohingya were threatened with death to leave Myanmar, and landmines were laid along the Myanmar-Bangladesh border by the military. ${ }^{41}$ The Myanmar government constructed their typical narrative, arguing that Rohingya burned down their own homes, faked their own injuries, and that the ARSA was responsible for the population displacement - all of which is unequivocally false. ${ }^{42}$ In many of the attacks, soldiers worked side by side with Rakhine Buddhists, "hacking people to death, beheading them, even killing children." ${ }^{43}$ As of September 2017, 420,000 Rohingya had fled the violence, among them 240,000 children. ${ }^{44}$ By January 2018, the number of Rohingya remaining in Rakhine state was estimated at 250,000 , down from 1.3 million five years prior, which means that a total of between nine hundred thousand to 1.17 million Rohingya refugees are currently residing in Bangladesh. Around 671,000 of these refugees have migrated since August $2017 .{ }^{45}$ The crisis could escalate further, leaving only one hundred thousand by next year. ${ }^{46}$ Furthermore, Rohingya are currently barred from re-entering the country since only those with "proof of nationality" — something Rohingya have been systematically denied - is required. ${ }^{47}$

The Myanmar government prefers to obfuscate the violence perpetrated against Rohingya Muslims in Rakhine state, and has been able to use ARSA as a scapegoat. ARSA has been labelled as a terrorist organization for its violent crimes and is being blamed for the unrest in Rakhine and for the plight of the Rohingya. Therefore, this section will discuss the viability of labelling the Rohingya crisis as an 'insurgency,' and will ultimately conclude that this characterization is inaccurate.

There have been other insurgencies in Rakhine between the 1970s and late 1990s, most notable being the Rohingya Solidarity Organization (RSO) and the Rohingya National Army, who launched small-scale border raids across the Bengali border.48 The Myanmar government claimed that the RSO was responsible for attacks on border police in 2014 which killed four officers. ${ }^{49}$ As violence and fear drew attention the Rohingya 
in 2012, Rakhine people feared another insurgency along the lines of the Taliban or ISIS. ${ }^{50}$ In 2013 a new group called the Harakah al-Yaqin (HaY) would be founded by Saudi Rohingya émigrés with "experience in modern guerrilla war tactics" and began recruiting in Bangladesh and Northern Rakhine to 'defend' Rohingya in Myanmar. ${ }^{51}$ The International Crisis Group (ICG) reports that hundreds of villagers have been recruited since 2014 and provided with basic military training. ${ }^{52}$ The leader of the group, Ata Ullah, is also from Saudi Arabia and has been leading operations for the group in the region with a collection of other Saudi Rohingyas. ${ }^{53} \mathrm{HaY}$ perpetrated the October 2016 attacks against Myanmar forces, and renamed itself to ARSA before the August 2017 attacks. This has prompted a counter-insurgency group led by Rakhine Buddhists, the Arakan Liberation Army, to increase its strength in Rakhine state and fight against ARSA. ${ }^{54}$

Despite this worrisome development in armed groups within Rakhine state, the threat they pose to fomenting a civil conflict or secessionist movement is rather marginal, and therefore, labeling the ethnic violence as an 'insurgency' is inaccurate. The RSO has been defunct since the early 2000s, and it is simply a convenient label for perpetrators to use, or for the government to blame. ${ }^{55}$ Despite the narrative extended by some Buddhists in the country, there are no links between insurgent groups and Islamic jihadist groups, and labelling ARSA as "Bengali terrorists" to justify excessive force is "distorted and manipulative." 56 ARSA does not have broader goals related to Islamic fundamentalism, and their stated purpose is to aid the Rohingya and secure their rights as citizens of Myanmar. ${ }^{57}$ The response of the Tatmadaw has also been disproportionate, killing hundreds through "area clearance operations" and displacing over eighty-eight thousand people. ${ }^{58}$ Lastly, the recent Fact-Finding report released by the Office of the United Nations High Commissioner for Human Rights (OHCHR) noted that the Myanmar government has published photos and names of 1,300 supposed ARSA terrorists without due process, and that throughout their interviews, no Rohingya mentioned ARSA as a factor in fleeing Rakhine state. ${ }^{59}$ Overall, ARSA is a lowlevel insurgency group inflicting minimal casualties on Myanmar forces. Although posing a threat to government forces, the Tatmadaw has responded in kind with premeditated and ruthless retaliation against the civilian Rohingya population. This negates the Myanmar government narrative that the violence in Myanmar is the result of a Rohingya insurgency.

The term "ethnic cleansing" is a broad term to denote cases where an ethnic, national, or cultural group is being threatened with erasure by another group. This term has been applied to the Rohingya on numerous occasions. The United Nations High Commissioner for Human Rights has referred to the situation in Rakhine state as ethnic cleansing, as has the UN Flash Report regarding interviews with Rohingya refugees. ${ }^{60}$ Azeem Ibrahim and Zoltan Barany have also both labelled this conflict as ethnic cleansing. ${ }^{61}$ The US State Department has been very clear in its determination that ethnic cleansing is occurring in Rakhine state against the Rohingya, noting that Secretary of State Tillerson made the characterization himself. ${ }^{62}$

However, this terminology hides the truth. As noted through the work of Michael Mann, both "ethnic cleansing" and "murderous ethnic cleansing" could refer to very different situations, ranging from "voluntary assimilation" to "ethnocide" and "genocide." 63 The use of the term "ethnic cleansing" by these organizations is specifically to avoid terminology like "genocide." This is especially well-illuminated by the US State Department, when one official responded to a journalist who asked if genocide was occurring in Myanmar:

Unlike the term "ethnic cleansing," the terms "crimes against humanity" and "genocide" are specific crimes under international law and there is[sic] very serious legal consequences, and in the end it's really a court that has 
to decide that ... so we would need to do a much more - much deeper analysis, much more extensive legal analysis... But at this time, there's no determination of crimes against humanity or genocide. ${ }^{64}$

Ibrahim does suggest that Myanmar "stands on the brink of genocide."65 However, there is enough evidence presented since at least 2016 that systematic, planned genocide has been perpetrated against the Rohingya, and the United Nations High Commissioner for Refugees (UNHCR) contends that this may be the case. ${ }^{66}$ The precipice which Ibrahim refers to may have been between 2012 and 2015 instead, as Wade notes that scholars point to Myanmar post-2012 as possessing "precursors to historic instances of genocide elsewhere in the world" including broad dehumanization, sporadic violence, and denial of protection by the state. ${ }^{67}$

Genocide is a legal term in international law established through the Convention in 1949. Article I states that the term "genocide" can be applied "in peace or in time of war," while Article II denotes that genocide can be invoked when killing, causing serious bodily or mental harm. ${ }^{68}$ This includes inflicting conditions calculated to prevent births, forcibly transfer children to another group, or bring about the physical destruction of another group with "intent to destroy, in whole or in part, a national, ethnical, racial or religious group," and Article III notes that conspiracy to commit genocide, direct and public incitement to commit genocide, attempt to commit genocide, and complicity in genocide are all equivalent to the main charge of 'genocide. '69 The next section will test various aspects of the crisis affecting Rohingya in Rakhine state to determine whether a genocide is being perpetrated.

There is broad evidence for the mass killing of Rohingya in Rakhine state, most of which has been outlined above. Testimonies gathered by the UN confirm this, noting that the "the killing of babies, toddlers, children, women and elderly" is rather normal. ${ }^{70}$ This is the same for "bodily harm." One important area regarding "mental harm' is the impact of sexual violence and rape on women and girls. The UN interviews analyzed the conversations with approximately one hundred women. Out of this, 52 per cent of the interviewed women and girls experienced some form of sexual violence, 25 per cent of the interviewed experienced rape, with two survivors of rape being younger girls. ${ }^{71}$ The report notes that these numbers are very likely underestimated due to feelings of shame, the conservative culture which persists among Rohingya women, and the fact that some women had to be interviewed by men. ${ }^{72}$ The perpetrators told the survivors that one of the reasons for the violence was the fact that they were Rohingya, indicating the use of rape as a tool of ethnic violence. The UN Fact Finding mission corroborates this information, noting that some women and girls were even abducted and taken back to 'security forces' camps to be abused. ${ }^{73}$ This widespread sexual violence and rape, coupled with the higher rates of killing among Rohingya men, had enormous psychological impacts on Rohingya women and girls. Women who suffered sustained injuries could have difficulty having children in the future, and the frequently poor medical services in refugee compounds results in minimal support for PTSD and other mental health concerns.

The mass exodus of over 90 per cent of the Rohingya population should constitute "inflicting conditions designed to bring about the physical destruction of the group."74 The village burning, thieving, mass detentions in compounds with deplorable conditions, and destruction of food resources have destroyed the ability of Rohingyas to sustain themselves financially, forcing almost the entire ethnic group into refugee camps and forcing dependence on aid to survive. ${ }^{75} \mathrm{Ibrahim}$ argues that the detention camps were created specifically to eliminate the Rohingya. ${ }^{76}$ These camps are already widespread across Northern Rakhine, especially when taking into account the IDP camps, which severely limit the mobility of Rohingya who live in them. Worse still is that authorities require 
Rohingya to possess documents in order for them to travel between the five majority-Rohingya areas. ${ }^{77}$ These controls, at least in part, facilitate the destruction of the Rohingya by removing them from their land, destroying their ability to provide for themselves, and attempting to replace their identity with one rooted in fear.

The Rohingya have faced birth-restriction measures since the first procreation control laws were instituted in 2005 and have become more restrictive since. ${ }^{78}$ The Buddhist Women Special Marriage law passed in August 2015 introduced restrictions on non-Buddhist husbands. Rohingya men were required to wait up to a year obtain a permit, which was not expected of other ethnic groups, and could face fines and prison for failing to comply. ${ }^{79}$ This is in line with the purifying mission of Buddhists who would like to see a perfectly Burmese-Buddhist ethnostate, as preventing marriages prevents procreation. Further, Rohingyas have been restricted to two children per marriage. Ibrahim notes that this is below the domestic replacement rate for the group, which signals a concerted attempt by the Myanmar government to reduce the Rohingya population by attrition. ${ }^{80}$ Lastly, Rohingya children are unable to have their birth registered due to their non-citizenship. The lack of medical care in Northern Rakhine, with some places possessing only one doctor for 160,000 people, means only 2 per cent of women give birth in hospitals. ${ }^{81}$ This purposeful inaction by the government to aid the Rohingya prevents safe births and leads to high infant mortality rates, which is a direct threat to their ability to procreate.

The complicity of the Myanmar government in the Rohingya genocide, and also its intent to perpetrate genocide, rely on the important relationship between the military, Buddhist pressure, and governing legitimacy. The current ruling party headed by Aung San Suu Kyi, the National League for Democracy, is dependent on support from the Buddhist monks to remain in power, who have considerable influence over the stance of the NLD toward non-Buddhist groups. ${ }^{82}$ The monks are largely the hardliners within Theravada Buddhism, and are the primary proponents of linking Buddhism to Burmese citizenship. As a result, perpetrating violence against the Rohingyas has become a public way for both individuals and the state to profess their commitment to a Buddhist Myanmar. ${ }^{83}$ Furthermore, violence against the Rohingya has been mostly perpetrated either by state officials alone or in cooperation with other civilian groups. ${ }^{84}$

The initial report of the UN Fact-Finding Mission also has unique information regarding the conduct of security forces. The report accuses the Tatmadaw of premeditating the attacks led against Rohingya civilians after the August 2017 ARSA attacks:

The military took steps to build up its presence in Rakhine state in the weeks prior to the ARSA attacks, and there are strong indications that military activities increased across the three townships through August 2017. In multiple areas, the military launched its "clearance operations" within hours of the first attacks on 25 August. ${ }^{85}$

Similar "clearance missions" that were conducted in response to ARSA have taken place since then within Maungdaw, Buthidaung and Rathedaung townships without provocation. ${ }^{86}$ Also, the report notes that there are no accounts of security forces trying to protect Rohingya villagers, and Rohingya refugees interviewed said the Tatmadaw were both the greatest fear among Rohingya and the main perpetrators of violence. ${ }^{87}$ This new information, surely to be expanded upon in the final release of the Fact-Finding mission, indicates a high level of planning, premeditation, and sophistication within the Myanmar regime to eradicate the Rohingya. This shows clear intent to destroy, in whole or in part, the Rohingya people.

In conclusion, the violence 
perpetrated against Rohingya Muslims in Myanmar should be defined as a genocide. The systematic oppression, subjugation, and erasure of the Rohingya has existed since independence in 1948, rooted in an extremist version of Theravada Buddhism which sees the state as the ultimate guarantor of Buddhist purity. The Rohingya were deprived of their citizenship and ostracized as the outgroup, characterized as "terrorists" intending to "Islamize" Myanmar. The military painted the Rohingya as an existential threat to the existence of Burmese-Buddhist identity, which Rakhine Buddhists largely adhered to. Large-scale violence erupted in 2012, and again in 2016 and 2017 after democratization worsened animosity toward the Rohingya. Each time, a combination of civilians and government officials perpetrated genocide against the Rohingyas. "Insurgency" and "ethnic cleansing" obscure the reality of the situation in Rakhine state, which can only be characterized as a genocide according to the Convention.

She described how loud the sound of the gunfire was, and how villagers were hiding in the latrines and a pond to save their lives. She recalled how women were holding their babies tightly in despair, and how men and women were brought to a paddy field and separated. The group was shot at and her husband was one of many killed by gunfire. She felt powerless because she was unable to save him. In the midst of all of that, she was trying to find her children. I stress that this is not among the most dramatic testimonies we have taken but, incredibly, a rather typical one..$^{88}$

\section{ENDNOTES:}

1. Michael Mann, The Dark Side of Democracy:

Explaining Ethnic Cleansing, (Cambridge:

Cambridge University Press, 2005), 12.

2. Ibid., 4.

3. Ibid., 6

4. Ibid., 6.

5. Francis Wade, Myanmar's Enemy Within:

Buddhist Violence and the Making of a Muslim 'other', (London: Zed Books, 2017), 57.

6. Mikael Gravers, "Disorder as Order: The Ethno-Nationalist Struggle of the Karen in Burma/ Myanmar-A Discussion of the Dynamics of an Ethicized Civil War and Its Historical Roots," Journal of Burma Studies 19, no. 1 (2015): 34. 7. Elliott Prasse-Freeman, "The Rohingya crisis," Anthropology Today 33, no. 6 (2017), 2.

8. Wade, Myanmar's Enemy Within, 78.

9. Azeem Ibrahim, The Rohingyas: Inside

Myanmar's Hidden Genocide, (London: C. Hurst \& Co. Ltd., 2016), 81-82

10. Ibid., 47.

11. Ibid., 103.

12. Wade, Myanmar's Enemy Within, 20-21.

13. Ibid., 27.

14. Ibrahim, The Rohingyas, 41-42.

15. Wade, Myanmar's Enemy Within, 31.

16. Ibid., 82.

17. Alan Collins, "Burma's civil war: A case of societal security," Civil Wars 5, no. 4 (2002), 126.

18. Wade, Myanmar's Enemy Within, 34.

19. Ibrahim, The Rohingyas, 50-51; Wade, Myanmar's Enemy Within, 29.

20. Wade, Myanmar's Enemy Within, 29, 34.

21. Ibid., 92-94.

22. Ibid., 48-50.

23. Ibid., 11-12, 51.

24. Ibrahim, The Rohingyas, 73.

25. State Department, Burma 2016 Human

Rights Report, (Washington D.C.: Government

Printing Office, 2016), 31, https://www.state.gov/ documents/organization/265536.pdf; Chris Beyrer and Adeeba Kamarulzaman, "Ethnic cleansing in Myanmar: the Rohingya crisis and human rights," The Lancet 390, no. 10102 (September 2017), 1571; Tun Khin, "Rohingya: A Preventable 
Genocide Allowed to Happen," Insight Turkey 19, no. 4 (2017), 55.

26. Wade, Myanmar's Enemy Within, 21.

27. Ibid., 14-15.

28. Ibid., 57.

29. Beyrer and Kamarulzaman, "Ethnic cleansing in Myanmar," 1570.

30. Ibrahim, The Rohingyas, 102.

31. Ibid., 97-100.

32. Ibid., 108.

33. Mann, The Dark Side of Democracy, 4.

34. Wade, Myanmar's Enemy Within, 12-14.

35. International Crisis Group, Myanmar: A New

Muslim Insurgency in Rakhine State, (Brussels:

Internatioal Crisis Group, 2016), 35, https://

d2071 andvip0wj.cloudfront.net/283-myanmar-a-

new-muslim-insurgency-in-rakhine-state.pdf.

36. Ibrahim, The Rohingyas, 134.

37. International Crisis Group, "A New Muslim Insurgency," 6.

38. Zoltan Barany, "Burma: Suu Kyi's Missteps," Journal of Democracy 29, no. 1 (2018), 14; Khin, "A Preventable Genocide," 50; State Department, "Burma 2016 Human Rights Report," 33.

39. International Crisis Group, "A New Muslim Insurgency," 8.

40. Khin, "A Preventable Genocide," 43.

41. Beyrer and Kamarulzaman, "Ethnic cleansing in Myanmar," 1570.

42. Prasse-Freeman, "The Rohingya crisis," 1.

43. Khin, "A Preventable Genocide," 44.

44. Beyrer and Kamarulzaman, "Ethnic cleansing in Myanmar," 1570.

45. Stephanie Nebehey and Simon Lewis, "Acts of Genocide' Suspected Against Rohingya in Myanmar: U.N," Reuters, last modified March 7, 2018, https://www.reuters.com/article/usmyanmar-rohingya-rights/acts-of-genocidesuspected-against-rohingya-in-myanmar-u-nidUSKCN1GJ163

46. Khin, "A Preventable Genocide," 45.

47. Beyrer and Kamarulzaman, "Ethnic cleansing in Myanmar," 1571.

48. International Crisis Group, "A New Muslim Insurgency," 4; Wade, Myanmar's Enemy Within, 82-83.
49. International Crisis Group, "A New Muslim Insurgency," 4.

50. Wade, Myanmar's Enemy Within, 83.

51. International Crisis Group, "A New Muslim Insurgency," i.

52. International Crisis Group, "A New Muslim Insurgency," i, 15.

53. Ibid., 13.

54. Ibid., 8.

55. Ibid., 4.

56. Barany, "Suu Kyi's Missteps," 15; Ibrahim, The Rohingyas, 142.

57. International Crisis Group, "A New Muslim Insurgency," 14.

58. Office of the High Commissioner for Human Rights, Interviews with Rohingyas Fleeing from Myanmar Since 9 October 2016: Report of OHCHR Mission to Bangladesh, (New York: OHCHR, 2017), 42, http://www.ohchr.org/ Documents/Countries/MM/FlashReport3Feb2017. pdf.

59. Marzuki Darusman, "Statement by Chairperson of the Independent International Fact-Finding Mission on Myanmar" (speech, 37th session of the UN Human Rights Council, United Nations Human Rights Council, Geneva, March 12, 2018).

60. Office of the High Commissioner for Human Rights, "Interviews with Rohingyas," 42; Beyrer and Kamarulzaman, "Ethnic cleansing in Myanmar," 1571.

61. Barany, "Suu Kyi's Missteps," 14; Ibrahim, The Rohingyas, 97.

62. State Department Officials, "Senior State Department Officials On the Situation in Burma," by Various Interviewers, US Department of State, last modified November 22, 2017, https://www. state.gov/r/pa/prs/ps/2017/11/275855.htm.

63. Mann, The Dark Side of Democracy, 12.

64. State Department Officials, "On the Situation in Burma."

65. Ibrahim, The Rohingyas, 117.

66. Nebehey and Lewis, "'Acts of Genocide' Suspected."

67. Wade, Myanmar's Enemy Within, 96-97.

68. United Nations General Assembly, The 
Convention on the Prevention and Punishment of the Crime of Genocide, (Brussels: United Nations, 1949), https://treaties.un.org/doc/publication/unts/ volume\%2078/volume-78-i-1021-english.pdf

69. Ibid.

70. Office of the High Commissioner for Human

Rights, "Interviews with Rohingyas," 42.

71. Ibid., 20.

72. Ibid., 10.

73. Darusman, "Fact-Finding Mission on Myanmar."

74. United Nations General Assembly, The Convention on the Prevention and Punishment of the Crime of Genocide, (Brussels: United Nations, 1949), https://treaties.un.org/doc/publication/unts/ volume $\% 2078 /$

75. Office of the High Commissioner for Human Rights, "Interviews with Rohingyas," 41; Nebehey and Lewis, "Acts of Genocide' Suspected."

76. Ibrahim, The Rohingyas, 117.

77. State Department, "Burma 2016 Human Rights Report," 27.

78. Wade, Myanmar's Enemy Within, 92-94.

79. State Department, "Burma 2016 Human

Rights Report," 13.

80. Ibrahim, The Rohingyas, 126.

81. Khin, "A Preventable Genocide," 46-47.

82. Ibrahim, The Rohingyas, 79.

83. Ibid., 80.

84. Ibid., 129.

85. Darusman, "Fact-Finding Mission on Myanmar."

86. Ibid.

87. Ibid.

88. Ibid.

\section{BIBLIOGRAPHY:}

Barany, Zoltan. "Burma: Suu Kyi's Missteps." Journal of Democracy 29, no. 1 (2018), 5-19.

Beyrer, Chris, and Adeeba Kamarulzaman.

"Ethnic cleansing in Myanmar: the Rohingya crisis and human rights." The Lancet 390, no. 10102 (September
2017), 1570-1573.

Collins, Alan. "Burma's civil war: A case of societal security." Civil Wars 5, no. 4 (2002), 119-134.

Darusman, Marzuki. "Statement by Chairperson of the Independent International Fact-Finding Mission on Myanmar." Speech, 37th session of the UN Human Rights Council, United Nations Human Rights Council, Geneva, March 12, 2018.

Gravers, Mikael. "Disorder as Order: The Ethno-Nationalist Struggle of the Karen in Burma/Myanmar-A Discussion of the Dynamics of an Ethicized Civil War and Its Historical Roots." Journal of Burma Studies 19, no. 1 (2015), 27-78.

Ibrahim, Azeem. The Rohingyas: Inside Myanmar's Hidden Genocide. London: C. Hurst \& Co. Ltd., 2016.

International Crisis Group. Myanmar: A New Muslim Insurgency in Rakhine State. Brussels: International Crisis Group, 2016. https://d2071andvip0wj. cloudfront.net/283-myanmar-a-newmuslim-insurgency-in-rakhine-state. pdf.

Khin, Tun. "Rohingya: A Preventable Genocide Allowed to Happen." Insight Turkey 19, no. 4 (2017), 43-53.

Mann, Michael. The Dark Side of Democracy: Explaining Ethnic Cleansing. Cambridge: Cambridge University Press, 2005.

Nebehey, Stephanie, and Simon Lewis. "'Acts of Genocide' Suspected 
Against Rohingya in

Myanmar: U.N." Reuters. Last

modified March 7, 2018. https://www.

reuters.com/article/us-myanmar-

rohingya-rights/acts-of-genocide-

suspected-against-rohingya-in-

myanmar-u-n-idUSKCN1GJ163.

Office of the High Commissioner for Human

Rights. Interviews with Rohingyas

Fleeing from Myanmar Since 9

October 2016: Report of OHCHR

Mission to Bangladesh. New York:

OHCHR, 2017. http://www.ohchr.org/

Documents/

Countries/MM/FlashReport3Feb2017.pdf.

Prasse-Freeman, Elliott. "The Rohingya crisis." Anthropology Today 33, no. 6 (2017), 1-2.

State Department Officials. "Senior State Department Officials On the Situation in Burma." By Various Interviewers. US Department of State. Last modified November 22, 2017. https:// www.state.gov/r/pa/prs/ps/2017/11 275855.htm.

State Department. Burma 2016 Human Rights Report. Washington D.C.: Government Printing Office, 2016. https://www.state.gov/ documents/organization/ 265536.pdf.

United Nations General Assembly. The Convention on the Prevention and Punishment of the Crime of Genocide. Brussels: United Nations, 1949. https://treaties.un.org/doc/ publication/unts/volume $\% 2078 /$ volume-78-i-1021-english.pdf.

Wade, Francis. Myanmar's Enemy Within: Buddhist Violence and the Making of a Muslim 'other'. London: Zed Books, 2017. 